\title{
2D-DIGE proteome analysis on the platelet proteins of patients with major depression
}

\author{
Tiao-Lai Huang ${ }^{1 *}$, Mei-Lan Sung ${ }^{1}$ and Tai-Yuan Chen $^{2^{*}}$
}

\begin{abstract}
Introduction: Platelet activation is related to the psychopathology of major depression. We attempted to search and identify protein biomarkers from the platelets of patients with major depression. High resolution two-dimensional Differential Gel Electrophoresis (2D-DIGE), the matrix-assisted laser desorption/ionization time-of-flight mass spectrometry (MALDI-TOF MS), Western blot, and bioinformatic tools were applied to examine the platelet proteins of 10 patients with major depression and 10 healthy controls.

Results: The levels of 8 proteins were significantly different between the patients with major depression in the acute phase and healthy controls. The levels of protein disulfide-isomerase A3 (PDIA3) and F-actin-capping protein subunit beta (CAPZB) were higher in patients with major depression than in healthy controls. The levels of fibrinogen beta chain (FIBB), fibrinogen gamma chain (FIBG), retinoic acid receptor beta (RARB), glutathione peroxidase 1 (GPX1), SH3 domain-containing protein 19 (SH319), and T-complex protein 1 subunit beta (TCPB) were lower in patients with major depression than in healthy controls.
\end{abstract}

Conclusions: Platelet provided valuable information about the pathways and processes of inflammation/immunity, oxidative stress, and neurogenesis, related to major depression.

Keywords: 2D-DIGE, Western blot, Major depression, Platelet, Fibrinogen

\section{Background}

Several theories have been proposed regarding the pathogenesis of major depression, including the monoamine theory of norepinephrine and serotonin (5-HT), systemic immune activation, and neuroplasticity regulation of brain-derived neurotrophic factors (BDNF). In addition, the role of tissue-type plasminogen activators has also been linked to BDNF from the viewpoint of platelets [1-7], which are related to BDNF and serotonin release $[8,9]$. Furthermore, many papers have discussed the role of platelet activation in the psychopathology of major depression [10-14].

In our previous study, we developed a technique combining acid hydrolysis with matrix-assisted laser desorption/ ionization time-of-flight mass spectrometry (MALDI-TOF MS) for the rapid study of changes in the serum levels of

\footnotetext{
*Correspondence: a540520@adm.cgmh.org.tw; tychen@mail.ntou.edu.tw 1Department of Psychiatry, Kaohsiung Chang Gung Memorial Hospital and Chang Gung University College of Medicine, 123 Ta-Pei Road, Niao-Sung, Kaohsiung 833, Taiwan

${ }^{2}$ Department of Food Science, Center of Excellence for the Oceans, National Taiwan Ocean University, 2 Pei-Ning Road, Keelung 202, Taiwan
}

positive and negative acute phase protein biomarkers in patients with major depression. The results suggested that patients with major depression had an increased level of fibrinogen or a decreased level of transferrin [15]. These molecules were related to the platelets.

MALDI-TOF mass spectrometers are extremely sensitive instruments and have now been accepted as a major analytical tool for the detection, identification, and characterization of large biomolecules [16-18]. Twodimensional differential gel electrophoresis (2D-DIGE) using CyDye DIGE Fluor minimal dyes has also been established and used for studying the differential expression of proteins $[19,20]$.

A recent review has deeply elucidated that a bidirectional relationship between major depression and cardiovascular disorder (CVD), associated with shared inflammatory and oxidative and nitrosative stress (IO\&NS) pathways [21]. Lines of evidence showed that IFN $\gamma$, a Th-1-like cytokine which production is increased in major depression [22], is a significant factor in atherogenesis and coronary artery disease (CAD) [23]. The other pro-inflammatory cytokines that are increased in depression and that plays a role in

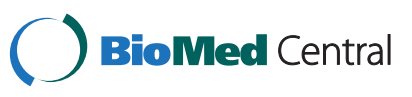


CAD are IL-12 [24], IL-1 type, IL-8 [25], IL-2, IL-6 and TNF- $\alpha[26,27]$. The patients with major depression and animal models of depression were accompanied by induction of IO\&NS pathways. The radical oxygen (ROS) and nitrogen species (RNS) production, demonstrated by increase levels of peroxide [28], nitric oxide (NO) productions $[29,30]$ and xanthine oxidase (XO) activity [31] that may react with fatty acid, proteins and DNA, and caused damage.

Recent studies demonstrate that BDNF [32,33], neurotrophin-3 (NT-3) [34], glial cell line-derived neurotrophic factor (GDNF) [35], fibroblast growth factor-2 (FGF-2) [36] and nerve growth factor (NGF) [37] influence adult hippocampal neurogenesis and regulate synaptic plasticity in neuronal networks involved in major depression. Furthermore, BDNF signaling was found to be associated with phosphoinositol dependent kinase 3, Akt and glycogen synthase kinase (GSK3) pathways [38-40].

It remains unclear that differences of the platelet protein between patients with major depression and healthy controls. Therefore, in the present study, we attempted to use the proteomic methods of 2D-DIGE, MALDITOF MS, Western blot and bioinformatic tools to compare the platelet protein profile between patients with major depression and healthy controls.

\section{Results}

This study recruited 10 patients (mean age $=37.2$ $(+/-9.3)$ years; mean body mass index $=24.2(7.0) \mathrm{kg} / \mathrm{m}^{2}$; female $/$ male $=6: 4$ ) and 10 healthy controls (mean age $=33.1$ $(+/-6.3)$ years; mean body mass index $=22.8(2.7) \mathrm{kg} / \mathrm{m}^{2}$; female $/$ male $=6: 4)$. The relative increase of at least 1.5 -fold in the abundance of protein spots in normal and patient samples is shown in Table 1. The items include mascot score, protein ID, accession number, protein name, $\mathrm{Mr} / \mathrm{PI}$ and sequence coverage. Moreover, all matched and unmatched masses, the matched peptide sequences information, enzyme cleavage specificity, any modification and deviations were provided in the Additional file 1: Table S1.

Eight proteins were identified among the patients with major depression in the acute phase and healthy controls (Figure 1). The levels of protein disulfide-isomerase A3 (PDIA3) and F-actin-capping protein subunit beta (CAPZB) were higher in patients with major depression than in healthy controls. The levels of 6 proteins, fibrinogen beta chain (FIBB), fibrinogen gamma chain (FIBG), retinoic acid receptor beta (RARB), glutathione peroxidase 1 (GPX1), SH3 domain-containing protein 19 (SH319), and T-complex protein 1 subunit beta (TCPB) were lower in patients with major depression than in healthy controls.

However, because of the limited platelet amounts, only 7 patients and 7 controls (age- and sex-matched) were examined for protein validation by western blot analysis. Among the identified proteins, protein disulfide-isomerase A3 (PDIA3), fibrinogen beta chain (FIBB), glutathione peroxidase 1 (GPX-1), and retinoic acid receptor beta (RARB) were validated by western blotting. The results are shown in Figure 2. PDIA3 was up-regulated in the patients, whereas FGB, GPX-1, and RARB were down-regulated in the patients. Protein levels were quantified by densitometric analysis with the control being set at 1 . Data presented as means $\pm \mathrm{SD}$ of three independent experiments for each sample. The GPX1, FIBB and RARB were $0.66 \pm 0.15$, $0.45 \pm 0.12$ and $0.68 \pm 0.17$, respectively. The PDIA3 was $1.96 \pm 0.39$. The western blot analysis results of these 4 differentially expressed proteins were in agreement with the 2-D PAGE expression data.

We used bioinformatic tools to classify these eight significantly differential display proteins. The identified proteins were mainly distributed in the cytoplasm, followed by nucleus and secreted form (Table 2). The protein SH319 and RARB located in the nucleus, but FIBB and

Table 1 Relative changes in the abundance of different protein spots with at least 1.5 -fold in control and patient samples

\begin{tabular}{|c|c|c|c|c|c|c|c|}
\hline Spot no. & Mascot score & ID & Accession no. & Protein name & $\mathrm{Mr} / \mathrm{PI}$ & $\mathrm{SC}$ & Description \\
\hline $\mathrm{H} 3(872)$ & 88 & FIBB & P02675 & Fibrinogen beta chain & $55 / 8.5$ & 35 & $N>P$ \\
\hline $\mathrm{H} 4(867)$ & 62 & FIBB & P02675 & Fibrinogen beta chain & $55 / 8.5$ & 26 & $N>P$ \\
\hline H6(1026) & 72 & FIBB & P02675 & Fibrinogen beta chain & $55 / 8.5$ & 29 & $N>P$ \\
\hline$H 7(1023)$ & 114 & $\mathrm{TCPB}$ & P78371 & T-complex protein 1 subunit beta & $57 / 6.0$ & 41 & $N>P$ \\
\hline G11(1014) & 57 & FIBG & P02679 & Fibrinogen gamma chain & $51 / 5.3$ & 18 & $N>P$ \\
\hline G13(1534) & 63 & SH319 & Q5HYK7 & SH3 domain-containing protein 19 & $86 / 8.5$ & 11 & $N>P$ \\
\hline G15(812) & 61 & RARB & P10826 & Retinoic acid receptor beta & $50 / 8.0$ & 11 & $N>P$ \\
\hline H16(1572) & 57 & GPX1 & P07203 & Glutathione peroxidase 1 & $21 / 6.1$ & 23 & $N>P$ \\
\hline G1(791) & 86 & PDIA3 & P30101 & Protein disulfdte-isomerase A3 & $56 / 5.9$ & 25 & $\mathrm{P}>\mathrm{N}$ \\
\hline $\mathrm{H} 2(786)$ & 94 & PDIA3 & P30101 & Protein disulfide-isomerase $\mathrm{A} 3$ & $56 / 5.9$ & 30 & $\mathrm{P}>\mathrm{N}$ \\
\hline G14(1317) & 70 & CAPZB & P47756 & F-actin-capping protein subunit beta & $31 / 5.3$ & 26 & $P>N$ \\
\hline
\end{tabular}

SC: sequence coverage. 

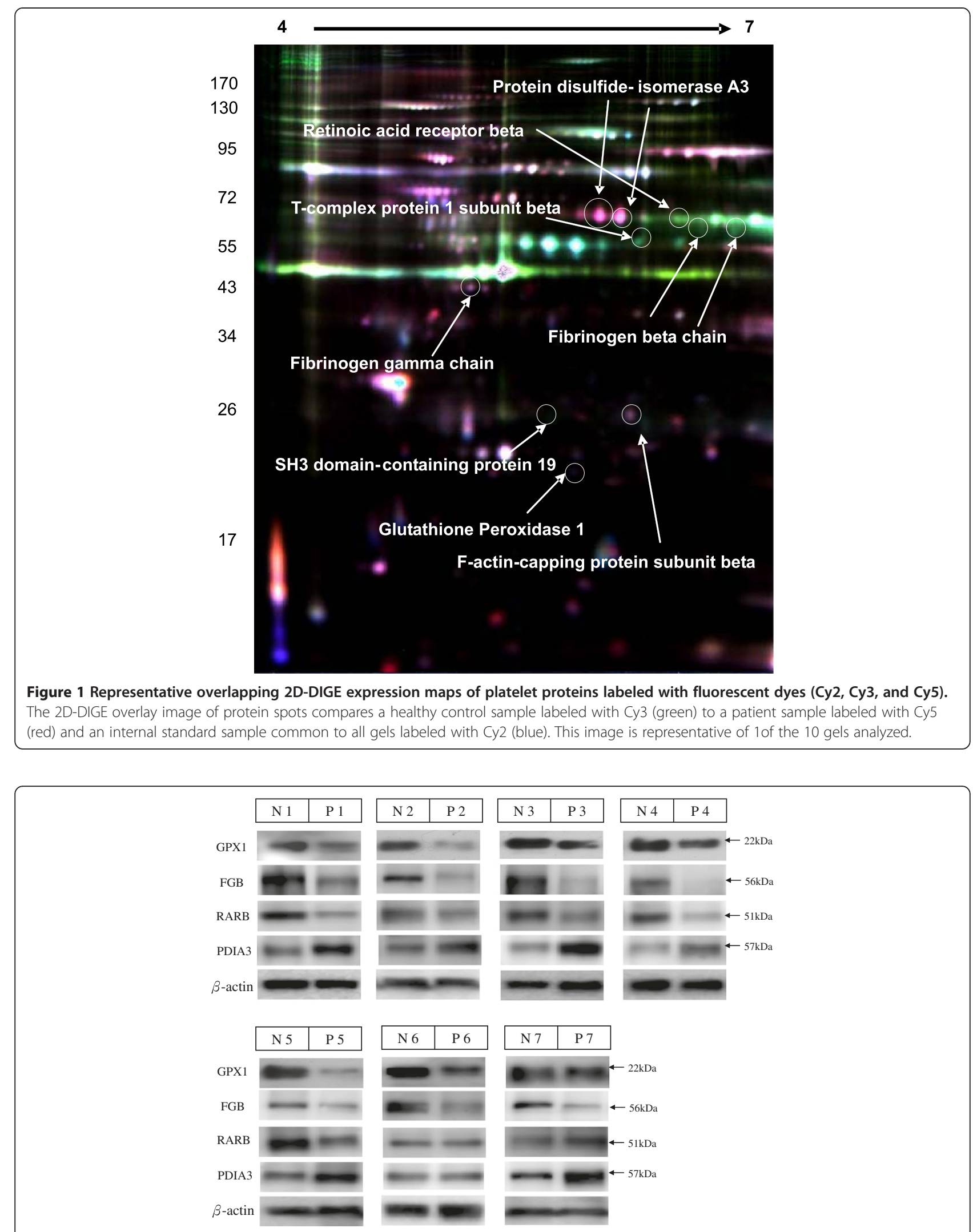

Figure 2 Western blot analysis of human platelet proteins. Validation of PDIA3, FGB (FIBB), GPX1, and RARB. Nos. N1-N7 indicate healthy control samples, and Nos. P1-P7 indicate patient samples. 
Table 2 Functional classification of differentially expressed platelet proteins between healthy control and patients with major depression by using BiNGO 2.44 software

\begin{tabular}{ll}
\hline Component & Protein symbols* \\
\hline Cytoplasm & FIBB, FIBG, TCPB, GPX1, \\
Membrane-bound vesicle & FIBG, PDIA3, FIBB \\
Stored secretory granule & FIBG, FIBB \\
Nucleus & SH319, RARB \\
Chaperone-containing T-complex & TCPB \\
Molecular function & \\
Protein binding & FIBB, FIBG, TCPB, GPX1, \\
Cell surface binding & FIBG, RARB, GPX1, PDIA3 \\
Retinoic acid receptor activity & FIBG, FIBB \\
Proline-rich region binding & RARB \\
Intramolecular oxidoreductase activity & SH319 \\
Glutathione peroxidase activity & PDIA3 \\
Biological process & GPX1 \\
Wound healing, response to metal ion & FIBG, FIBB, GPX1 \\
Positive regulation of cell death & PDIA3, RARB, GPX1 \\
Protein polymerization & FIBG, FIBB \\
Muscle cell differentiation & RARB, GPX1 \\
Cell redox homeostasis & PDIA3, GPX1 \\
\hline
\end{tabular}

*FIBB: fibrinogen beta chain, TCPB: T-complex protein 1 subunit beta, GPX1: glutathione peroxidase 1, FIBG: fibrinogen gamma chain, RARB: retinoic acid receptor beta, PDIA3: protein disulfide-isomerase A3.

FIBG were secreted according to UniProtKB/Swiss-Prot and GO databases. Primary molecular function was binding and these identified proteins abundantly bind to protein, nucleotides, nucleic acid, receptor, chaperone and actin (Table 2). The second molecular function was enzyme activity including retinoic acid receptor, transposing S-S bonds and glutathione peroxidase (Table 2). Further studies were performed to construct protein-protein interaction network and analyze correlation between disease and identified proteins by the Metacore from GeneGo Inc. Nodes with varied symbols stand for different types of proteins and lines with different colors between nodes indicate different protein-protein regulation modes. Moreover, we put these eight identified protein together and tried to assemble protein-protein correlationships (Figure 3). There are mainly two transcription factor, namely SP1 and AP-1 inclusive in the protein network. Other transcription factor includes ERK1/2, c-Jun, c-Myc, c-Fos, RelA, HSF1, Elk-1, STAT3, NF-kB, Oct-3/4 and SP3. The membrane receptors primarily are integrin family (alpha 2 , alpha 4 , beta1, alpha 4/beta 1 , alpha 5/beta 1 , alpha 5/beta 3), Plexin A1, Thrombomodulin, Tissue factor.

The SH319 and PDIA3 seem to be excluded; however, both of them were indirectly related to SP1. The SH319 and SP1 activate a disintegrin and metalloprotease domain 17 (ADAM 17), as a tumor necrosis factor-alpha converting enzyme (TNF-alpha converting enzyme, TACE); binds mitotic arrest deficient 2 protein; and also involves in the activation of the Notch signaling pathway. The PDIA3 activate calreticulin (molecular calcium-binding chaperone) to hamper the binding of androgen receptor to its hormone-responsive DNA element and inhibit retinoic acid receptor transcriptional activities in vivo. The PDIA3 and SP1 activate MMP-9 to degrade collagen IV \& V and fibronectin. The PDIA3 could also activate immune system through binding to MHC I for peptide antigen presentation and processing.

The eight identified proteins could be related to some disease developments according to Metacore database. Table 3 shows that skin and connective tissue diseases, breast neoplasms, pathologic processes, cardiovascular diseases, neuroectodermal tumors, neuroepithelial neoplasms, kidney diseases, wounds and injuries, and cerebrovascular disorders are associated with the identified proteins. The disease target proteins consist of FIBB, TCPB, GPX1, FIBG, RARB, and PDIA3. Among them, GPX1 and fibrinogen play ultimately crucial roles serving as biomarkers for multiple diseases.

\section{Discussion}

The most interesting finding in this study was higher PDIA3 expression and lower FGB, GPX-1, and RARB expression in patients with major depression than in healthy controls. Moreover, these proteins were validated by western blot.

PDIA3 is also known as a glucose-regulated protein; it is an isomerase enzyme with a molecular mass of $58 \mathrm{kDa}$ and is essential for the formation of the final antigen conformation and exportation from the endoplasmic reticulum to the cell surface [41-43]. Data regarding the relationship between PDIA3 and major depression are scarce. Previous studies showed that the pharmacological actions of antidepressant drugs most affected the metabolism of two neurotransmitters: serotonin and noradrenaline. However, many aspects of antidepressant action are not yet understood. McHugh et al. [44] used a proteomic analysis in a neuronal cell culture model to identify new molecules relevant to antidepressant action [44]. After antidepressant exposure, they observed increased expression of PDIA3, sepiapterin reductase (SPR), and heat shock protein and decreased expression of creatine kinase, a T-cell receptor alpha chain, defensin-related cryptdin 5 , and the intermediate filament protein glial fibrillary acidic protein. Therefore, PDIA3, SPR, and the other proteins identified might provide a link to the possible psychopathology of major depression. 


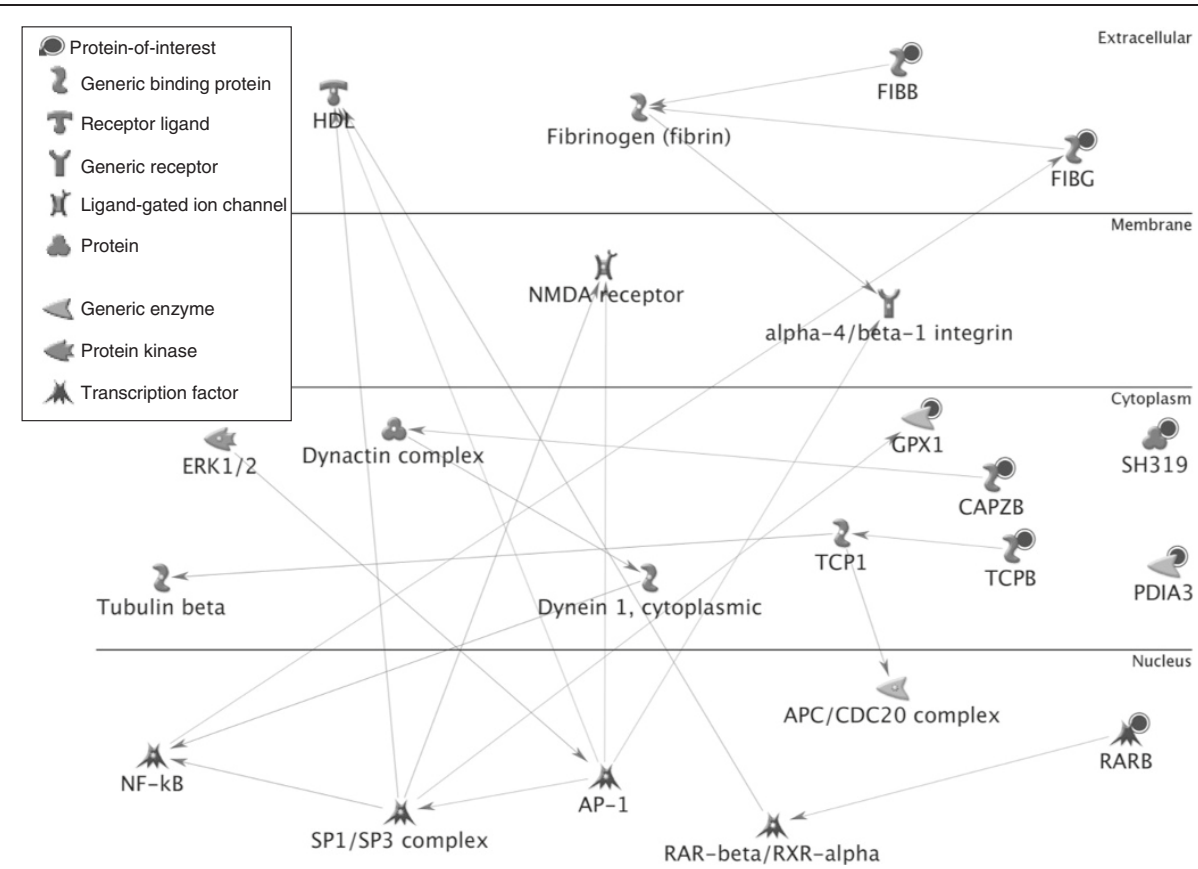

Figure 3 Networking construction of eight differentially expressed platelet proteins between healthy controls and patients with major depression using Metacore software from GeneGo Inc.

With regard to FIBB, many studies have discussed the relationship between inflammation and depression. The blood markers of inflammation, including myeloperoxidase (MPO), interleukin-6, white blood cell count, C-reactive protein, tumor necrosis factor (TNF)-alpha, and fibrinogen, were noted [45,46]. Vaccarino et al. [45] showed a strong association of MPO and weaker association of other inflammatory biomarkers with major depression [45]. In addition, Danese et al. [46] showed that in patients with a history of childhood maltreatment, depression was associated with high levels of high-sensitivity C-reactive protein [46]. On the other hand, Markovitz et al. [47] found that depressed patients had greater platelet secretion than the comparison subjects in response to collagen; further, platelet secretion in response to collagen was significantly reduced after treatment with sertraline, an antidepressant [47]. Furthermore, several studies have attempted to establish relationships between fibrinogen, platelet, serotonin, BDNF, and major depression [8-10].

With regard to GPX1, there is some evidence that the activation of the immune-inflammatory process, increase in monoamine catabolism, and abnormalities in lipid compounds may cause overproduction of reactive oxygen species (ROS) and, in turn, antioxidative enzyme activities (AEAs) and lipid peroxidation (LP). These phenomena may subsequently be related to the pathophysiology of major depression. The antioxidant enzymes include superoxide dismutase (SOD), catalase, and glutathione peroxidase (GPX) and beta-adrenergic receptors [48,49]. Bilici et al. [48] showed that patients with major depression, especially melancholic patients, had higher AEA and LP levels than those of healthy controls. After treatment for 3 months with antidepressants, AEA and LP levels of the patients significantly decreased to normal levels [48]. Although there was a decrease in nitrite content and betaadrenergic receptor binding in the patients with major

Table 3 Correlationship between diseases and eight differentially expressed platelet proteins between healthy controls and patients with major depression using Metacore software from GeneGo Inc

\begin{tabular}{ll}
\hline Disease & Protein symbols* \\
\hline Skin and connective tissue diseases & FIBB, TCPB, GPX1, FIBG, RARB \\
Breast Neoplasms & FIBB, TCPB, GPX1, FIBG, RARB \\
Pathologic processes & FIBB, GPX1, FIBG, RARB \\
Cardiovascular diseases & FIBB, GPX1, FIBG, RARB, PDIA3 \\
Neuroectodermal tumors & FIBB, GPX1, FIBG, RARB, PDIA3 \\
Neoplasms, neuroepithelial & GPX1, RARB, PDIA3 \\
Glioma & GPX1, RARB, PDIA3 \\
Kidney diseases & FIBB, GPX1, FIBG, RARB \\
Cerebrovascular disorders & FIBB, GPX1, FIBG \\
Wounds and injuries & FIBB, GPX1, FIBG
\end{tabular}

*FIBB: fibrinogen beta chain, TCPB: T-complex protein 1 subunit beta, GPX1: glutathione peroxidase 1, FIBG: fibrinogen gamma chain, RARB: retinoic acid receptor beta, PDIA3: protein disulfide-isomerase A3. 
depression as compared to that in the healthy controls, the activities of SOD, catalase, and GPX were not significantly altered in these patients [49]. However, major depression induced the increased risk for cardiovascular disorder (CVD) partially by significantly lower blood concentrations of major antioxidants and their enzyme activities as GPX [28,50]. Lang et al. [51] review molecular mechanisms of depression and search for perspectives on antidepressant treatment strategies [51].

With regard to RARB, several studies have recently shown that the molecular components required for retinoic acid signaling are expressed in the adult brain [52-54]. The overlap of brain areas implicated in retinoic acid function and stress and depression suggest that retinoids could play a role in affective disorders. Retinoids represent a family of compounds derived from vitamin A that perform a large number of functions, many via the vitamin A derivative retinoic acid. This signaling molecule binds to specific retinoic acid receptors in the brain, which, like the glucocorticoid and thyroid hormone receptors, are part of the nuclear receptor superfamily and regulate gene transcription [52]. An examination of vitamin-deprived animals revealed a progressive and ultimately profound impairment of hippocampal CA1 long-term potentiation. Importantly, these losses are fully reversible by dietary vitamin A replenishment in vivo or direct application of all trans-retinoic acids to acute hippocampal slices [53]. In a human study, Chen et al. [54] showed that retinoic acid receptors (RAR) might contribute to regulate the activity of corticotropinreleasing hormone $(\mathrm{CRH})$ neurons in vivo, and the vulnerable characteristic of the critical proteins in the retinoic acid (RA) signaling pathways might provide novel targets for therapeutic strategies for depression [54]. In addition, Katsuki et al. [55] revealed that RAR stimulation protects midbrain dopaminergic neurons from inflammatory degeneration via BDNF-mediated signaling [55]. Further, cyclindependent kinase 5 (CDK5) might influence the formation of memory and mood by affecting differential effects of glucocorticoid on BDNF expression [56]. These results also indicate that neuroplasticity should be involved in the psychopathology of major depression. The limitation of this study was that a wash-out period of 1 week is very short. The antidepressants included paroxetine 20 /day $(n=3)$, Venlafaxine $150 \mathrm{mg} /$ day $(\mathrm{n}=2)$, Mirtazapine $60 \mathrm{mg} /$ day $(n=2)$ and drug naïve $(n=3)$ in this study. We could not ascertain that there was has no effect on their results of the drug state of the patients.

\section{Conclusions}

These findings suggest that the processes of inflammation/immunity, oxidative stress, and neurogenesis are involved in the psychopathology of major depression. These biomarkers infer the shared inflammatory and oxidative and nitrosative stress pathways that may contribute to major depression and result in cardiovascular disorders. To our knowledge, this is the first study to investigate the platelet proteins of major depressive patients by using 2DDIGE, MALDI-TOF MS, and bioinformatic analyses. However, these data represent only preliminary results, and a large sample is needed to prove these results. In addition, the detailed functions of platelets in major depression need to be further studied in the future.

\section{Methods}

\section{Patients with major depression and healthy controls}

This study was conducted from December 2007 to November 2008 at Chang Gung Memorial Hospital (CGMH)-Kaohsiung Medical Center, Taiwan. The CGMH Ethics Committee formally issued an approval for this study. Patients suffering from major depression and healthy controls were selected according to the results of a Structured Clinical Interview for DSM-IV Axis I Disorders (SCID) [57]. Patients with other comorbid psychiatric disorders should be excluded, including bipolar disorder, schizophrenia, chronic fatigue syndrome and fibromyalgia. All the participants were free of liver, lung, renal, and metabolic diseases, and they did not take any medication for at least 1 week prior to entering this study.

\section{Separation of platelets from blood}

Blood sample was collected into 1.5 eppendorf tubes; thereafter, $100 \mu \mathrm{l}$ of ACD (acid-citrate-dextrose; Sigma C3821), $300 \mu \mathrm{l}$ of blood, and $660 \mu \mathrm{l}$ of $\mathrm{NaN}_{3} / \mathrm{PBS}(0.05 \%)$ were centrifuged at $250 \mathrm{~g}$ for $10 \mathrm{~min}$ at $10^{\circ} \mathrm{C}$. The supernatant was added to a new eppendorf tube and centrifuged at $1613 \mathrm{~g}$ for $10 \mathrm{~min}$ at $10^{\circ} \mathrm{C}$. Next, the supernatant was discarded, and the platelets were washed in $1 \mathrm{ml}$ of $\mathrm{NaN}_{3} /$ PBS (0.05\%). Thereafter, the platelets were centrifuged at $1613 \mathrm{~g}$ for $10 \mathrm{~min}$ at $10^{\circ} \mathrm{C}$. After the supernatant was discarded, $200 \mu \mathrm{l}$ of lysis buffer (8 M urea, 4\% CHAPS, $30 \mathrm{mM}$ Tris- $\mathrm{Cl}, \mathrm{pH} 8.5$ ) was added to the platelets, and they were stored at $-80^{\circ} \mathrm{C}$.

\section{D-DIGE analysis of the platelets}

Total protein was quantified in 10 pooled control samples and 10 pooled patient samples using the Bio-Rad protein assay. The platelet proteins were then concentrated, and impurities removed using the 2D Clean Up Kit. The final precipitated pellets were redissolved in $60 \mu \mathrm{l}$ of lysis buffer (8 M urea, 4\% CHAPS, $30 \mathrm{mM}$ Tris-Cl, pH 8.5), the total protein was quantified again, and the samples were stored on ice prior to subsequent Cy dye labeling. Each sample was labeled with $200 \mathrm{pmol}(1 \mu \mathrm{l})$ of Cy dye per $50 \mu \mathrm{g}$ of protein, incubated on ice for $30 \mathrm{~min}$ in the dark, and quenched with $1 \mu \mathrm{l}$ of $10 \mathrm{mM}$ lysine; each sample was then incubated on ice for $10 \mathrm{~min}$ in the dark, according to the manufacturer's protocol. Ten control and 10 patient 
samples $(50 \mu \mathrm{g}$ of protein each) were labeled separately with either Cy3 or Cy5, and the internal standard (200 $\mu \mathrm{g}$ of protein comprising $25 \mu \mathrm{g}$ from each of the 20 samples) was labeled with Cy2. One standard, control, and patient sample forming a set of Cy2-, Cy3-, and Cy5-labeled samples was combined for each of 10 gels and mixed with rehydration buffer (8 M urea, 1\% CHAPS, 0.5\% ASB14, $65 \mathrm{mM}$ DTT, $0.5 \% \mathrm{v} / \mathrm{v}$ pharmalytes $\mathrm{pH} 3-10,0.005 \%$ bromophenol blue) to a total volume of $250 \mu \mathrm{l}$ per gel. The first dimension separation was performed on an IPGphor isoelectric focusing (IEF) unit (GE Healthcare) by applying combined samples to immobilized $\mathrm{pH}$ gradient (IPG) 13-cm pH 4-7 strips with rehydration at $30 \mathrm{~V}$ for $16 \mathrm{~h}$ followed by isoelectric focusing at $500 \mathrm{~V}$ for $1 \mathrm{~h}, 1000 \mathrm{~V}$ gradient for $1 \mathrm{~h}$, and then $8000 \mathrm{~V}$ step for $32,000 \mathrm{~V} / \mathrm{h}$, for a total of $6 \mathrm{~h}$ and $30 \mathrm{~V}$. Strips were each immediately equilibrated in a $5 \mathrm{ml}$ solution of $6 \mathrm{M}$ urea, 30\% glycerol, $2 \%$ SDS, $75 \mathrm{mM}$ Tris- $\mathrm{Cl}$ (pH 8.8), and 0.005\% bromophenol blue for 15 min with $1 \%$ (w/v) DTT and subsequently for $15 \mathrm{~min}$ with $2.5 \%(\mathrm{w} / \mathrm{v})$ iodoacetamide (IAA). A molecular weight marker $(17-170 \mathrm{kDa})$ was added to one gel for reference. For the second dimension, strips were applied directly to $10 \%$ SDS-polyacrylamide gels, and 4 gels were run simultaneously on a SE600 (GE Healthcare) electrophoresis unit at $10^{\circ} \mathrm{C}$ at $0.35 \mathrm{~W} /$ gel for $16 \mathrm{~h}$. Immediately after 2D-DIGE, the gels were scanned with a Typhoon Trio imager using an excitation/emission filter of $488 / 520 \mathrm{~nm}$ for Cy2, 532/580 nm for Cy3, and 633/ $670 \mathrm{~nm}$ for Cy5 to generate multiplexed DIGE image files. Statistical and quantitative analyses of the spot changes on the images were completed using DeCyder software (GE Healthcare).

\section{In-gel digestion and protein identification}

Protein spots were excised from the gel, and the gel was washed 3 times with $200 \mu \mathrm{l} \mathrm{H}_{2} \mathrm{O}$ for 5 min by vortexing. The supernatant was discarded, and $200 \mu \mathrm{l}$ of destaining agent $\left(0.1 \mathrm{~g} \mathrm{~K}_{3} \mathrm{Fe}(\mathrm{CN})_{6}\right.$ and $0.16 \mathrm{~g} \mathrm{Na}_{2} \mathrm{~S}_{2} \mathrm{O}_{3}$ in $10 \mathrm{ml} \mathrm{dd}$ $\mathrm{H}_{2} \mathrm{O}$ ) were added by vortexing for $15 \mathrm{~min}$. The supernatant was again discarded, and the gel was washed 3 times in $200 \mu \mathrm{l}$ of washing solution I [ $50 \mathrm{mM} \mathrm{NH}_{4} \mathrm{HCO}_{3}$ / $100 \% \mathrm{ACN}(3: 2)]$ by vortexing for $15 \mathrm{~min}$. The supernatant was discarded, and $200 \mu \mathrm{l}$ of $100 \%$ ACN was added by vortexing for $10 \mathrm{~min}$. Then, the supernatant was discarded, with a vacuum centrifuge for $10 \mathrm{~min}$ at room temperature (RT). After adding 6-8 $\mu \mathrm{l}$ of trypsin buffer (25 $\mathrm{ng} / \mu \mathrm{l}$ trypsin, $25 \mathrm{mM} \mathrm{NH}_{4} \mathrm{HCO}$ ) to cover the gels, the gels were digested in trypsin solution for $16 \mathrm{~h}$ at $37^{\circ} \mathrm{C}$. The peptides obtained were extracted from the gel with extraction buffer (100\% acetonitrile, $1 \%$ trifluoroacetic acid), concentrated with a vacuum centrifuge for $10 \mathrm{~min}$ at room temperature (RT), and rehydrated by the addition of $10 \mu \mathrm{l}$ of deionized water.
Before their MS spectra and MS/MS fragment ion mass were determined with a Bruker MALDI-TOF/ TOF Analyzer (Bruker Daltonics, Bremen, Germany), all product ions were submitted to a computer database search analysis with the Mascot MS/MS ion search (Matrix Science Inc., MA) by using the SwissProt database (all entries). The Bruker operation system, namely flexControl Version 3.3 (Build 85) and flexAnalysis software were used to create peak lists.

MALDI-TOF/TOF data were searched in-house MASCOT software (ver 2.2.04). The following parameters were used: enzyme, trypsin; variable modification, carbamidomethyl and oxidation; mass values, monoisotopic; peptide mass tolerance, $\pm 100 \mathrm{ppm}$; peptide charge state, $1+$; maximum missed cleavage, 1 ; significance threshold, $p<0.05$. Peptide identification and protein assembly were performed in multiple stages. The protein identifications required detection of unique peptides and proteins with more than two spectral counts were selected for further analysis. The peptide mass data of each spot was submitted to the Swiss-Prot 100425 human species bioinformation stations using MASCOT search engines. Proteins identified with a higher MASCOT score in the bovine database than in the human database were considered as serum contamination and removed.

\section{Validation by western blotting and statistical analyses}

The data of the platelet proteins were analyzed using DeCyder software $(P<0.05$ in t-test; ratio of patient/normal $>1.5$ or $<1.5)$ in 10 patient and 10 control samples. However, because of the limited amount of platelets, only 7 patients and 7 controls (age and sex matched) were examined for protein validation by western blot analysis. Protein levels were quantified by densitometric analysis with the healthy control being set at 1 . Data presented as means $\pm \mathrm{SD}$ of three independent experiments for each sample.

\section{Bioinformatic tools for protein searches and networking construction}

The protein search programs used the following databases: NCBI (http://www.ncbi.nlm.nih.gov), and UniProtKB/SwissProt (http://www.uniprot.org/). In addition, the functional protein association networks or protein interactions were searched by STRING database (http://string-db.org/). The combining pathway databases of BioCarta (http://www.biocarta.com/genes/index.asp), KEGG (http://www.genome.jp/ kegg/pathway.html) and the PubMed literature (http://www. ncbi.nlm.nih.gov/pubmed/) were also used to search the correlated regulatory pathways in major depression and other related reactions. The MetaCore from GeneGo Inc. (Version 6.5) was applied in thoroughly compiling protein functional classification and interaction networks. 


\section{Additional file}

Additional file 1: Table S1. Protein identification by PMF searching using Mascot software (ver 2.2.04).

\section{Competing interests}

The authors declare that they have no competing interests.

\section{Authors' contributions}

TLH and TYC conceived and designed the study. TLH diagnosed the patients and MLS collected the samples. MLS and TYC carried out laboratory work, collation of data, data analysis. TYC carried out bioinformatic data analysis and interpretation of mass spectrometry data. TLH and TYC prepared the first draft of the manuscript. All authors agreed with the final manuscript.

\section{Acknowledgments}

We wish to thank Prof. Shiea J, National Sun Yat-Sen University, for valuable information with mass spectrometric analysis. This study was supported by research grants (CMRPG-860491 and CMRPG880251) from Chang Gung Memorial Hospital, Taiwan. In addition, we did not receive any support from any company.

Received: 28 May 2013 Accepted: 4 December 2013

Published: 3 January 2014

\section{References}

1. Maes M: Evidence for an immune response in major depression: a review and hypothesis. Prog Neuropsychopharmacol Biol Psychiatry 1995, 19:11-38.

2. Maes M, Lambrechts J, Bosmans E, Jacobs J, Suy E, Vandervorst C, de Jonckheere C, Minner B, Raus J: Evidence for a systemic immune activation during depression: results of leukocyte enumeration by flow cytometry in conjunction with monoclonal antibody staining. Psychol Med 1992, 22:45-53.

3. Maes M, Scharpe S, Van Grootel L, Uyttenbroeck W, Cooreman W, Cosyns P, Suy E: Higher alpha 1-antitrypsin, haptoglobin, ceruloplasmin and lower retinol binding protein plasma levels during depression: further evidence for the existence of an inflammatory response during that illness. J Affec Disord 1992, 24:83-192.

4. Hornig-Rohan M, Van Bell CT, Kuhn P, Amsterdam JD: Acute phase proteins in affective illness. Biol Psychiatry 1995, 37:607.

5. Hornig-Rohan M, Goodman DB, Kamoun M, Amsterdam JD: Immune dysfunction in affective subtypes. Biol Psychiatry 1996, 39:524.

6. Sluzewska A, Rybakowski JK, Bosmans E, Sobieska M, Berghmans R, Maes M, Wiktorowicz K: Indicators of immune activation in major depression. Psychiatry Res 1996, 64:161-167.

7. Khawaja X, XU J, Liang JJ, Barrett JE: Proteomic analysis of protein changes developing in rat hippocampus after chronic antidepressant treatment: implications for depressive disorders and future therapies. J Neurosci Res 2004, 75:451-460.

8. Tsai SJ: The possible role of tissue-type plasminogen activator and the plasminogen system in the pathogenesis of major depression. Med Hypotheses 2006, 66:319-322.

9. Tsai SJ: Statins may enhance the proteolytic cleavage of proBDNF: implications for the treatment of depression. Med Hypotheses 2007, 68:1296-1299.

10. Lee BH, Kim YK: Reduced platelet BDNF level in patients with major depression. Prog Neuropsychopharmacol Biol Psychiatry 2009, 33:849-853.

11. Mössner R, Mikova O, Koutsilieri E, Saoud M, Ehlis AC, Müller N, Fallqatter AJ, Riederer P: Consensus paper of the WFSBP Task Force on Biological Markers: biological markers in depression. World J Biol Psychiatry 2007, 8:141-174.

12. Ziegenhorn AA, Schulte-Herbrüggen $\mathrm{O}$, Danker-Hopfe H, Malbranc M, Hartung HD, Anders D, Lang UE, Steinhagen-Thiessen E, Schaub RT, Hellweq R: Serum neurotrophins-a study on the time course and influencing factors in a large old age sample. Neurobiol Aging 2007, 28:1436-1445.

13. Karege F, Bondolfi G, Gervasoni N, Schwald M, Aubry JM, Bertschy G: Low brain-derived neurotrophic factor (BDNF) levels in serum of depressed patients probably results from lowered platelet BDNF release unrelated to platelet reactivity. Biol Psychiatry 2005, 57:1068-1072.
14. Karege F, Perret G, Bondolfi G, Schwald M, Bertschy G, Aubry JM: Decreased serum brain-derived neurotrophic factor levels in major depressed patients. Psychiatry Res 2002, 109:143-148.

15. Lo L, Huang T, Shiea J: Acid hydrolysis followed by matrix-assisted laser desorption ionization mass spectrometry for rapid diagnosing of serum protein biomarkers in patients with major depression. Rapid Commun Mass Spectrom 2009, 23:589-598.

16. Tanaka K, Waki H, Ido Y, Akita S, Yoshida Y, Yoshida T, Matsuo T: Protein and polymer analyses up to $\mathrm{m} / \mathrm{z} 100000$ by laser ionization time-offlight mass spectrometry. Rapid Commun Mass Spectrom 1988, 2:151-153.

17. Nelson RW, Dogruel D, Willams P: Mass determination of human immunoglobulin IgM using matrix-assisted laser desorption/ionization time-of-flight mass spectrometry. Rapid Commun Mass Spectrom 1994, 8:627-631.

18. Karas M, Hillenkamp F: Laser desorption ionization of proteins with molecular masses exceeding 10,000 daltons. Anal Chem 1988, 60:2299-2301.

19. Kondo T, Hirohashi S: Application of highly sensitive fluorescent dyes (CyDye DIGE Fluor saturation dyes) to laser microdissection and two-dimensional difference gel electrophoresis (2D-DIGE) for cancer proteomics. Nat Protoc 2006, 1:2940-2956.

20. Kondo T, Seike M, Mori Y, Fujii K, Yamada T, Hirohashi S: Application of sensitive fluorescent dyes in linkage of laser microdissection and two-dimensional gel electrophoresis as a cancer proteomic study tool. Proteomics 2003, 3:1758-1766.

21. Maes M, Ruckoanich P, Chang YS, Mahanonda N, Berk M: Multiple aberrations in shared inflammatory and oxidative \& nitrosative stress (IO\&NS) pathways explain the co-association of depression and cardiovascular disorder (CVD), and the increased risk for CVD and due mortality in depressed patients. Prog Neuropsychopharmacol Biol Psychiatry 2011, 35:769-783.

22. Maes M, Scharpes S, Meltzer HY, Okayli G, Bosmans E, D'Hondt P, et al: Increased neopterin and interferon-gamma secretion and lower availability of L-tryptophan in major depression: further evidence for an immune response. Psychiatry Res 1994, 54:143-160.

23. Angerio AD: Interferon and heart disease. Crit Care Nurs Q 2009, 32:159-162.

24. Kim YK, Suh IB, Kim H, Han CS, Lim CS, Choi SH, et al: The plasma levels of interleukin-12 in schizophrenia, major depression, and bipolar mania: effects of psychotropic drugs. Mol Psychiatry 2002, 7:11071114.

25. Song C, Lin A, Bonaccorso S, Heide C, Verkerk R, Kenis G, et al: The inflammatory response system and the availability of plasma tryptophan in patients with primary sleep disorders and major depression. $J$ Affect Disord 1998, 49:211-219.

26. Dowlati Y, Herrmann N, Swardfager W, Liu H, Sham L, Reim EK, Lanctot KL: A meta-analysis of cytokines in major depression. Biol Phychiatry 2010, 67:446-457.

27. Schieoers OJ, Wichers MC, Maes M: Cytokines and major depression. Prog Neuropsycopharmacol Biol Psychiatry 2005, 29:201-217.

28. Maes M, Mihaylova I, Kubera M, Uytterhoeven M, Vrydags N, Bosmans E: Increased plasma peroxides and serum oxidized low density lipoprotein antibodies in major depression: markers that further explain the higher incidence of neurodegeneration and coronary artery disease. $J$ Affect Disord 2010, 125:287-294.

29. Chrapko WE, Jurasz P, Radomski MW, Lara N, Archer SL, Le Melledo JM: Decreased platelet nitric oxide synthase activity and plasma nitric oxide metabolites in major depressive disorder. Biol Psychiatry 2004, 56:129-134.

30. Maes M, Mihaylova I, Kubera M, Leunis JC: An IgM-mediated immune response directed against nitro-bovine serum albumin (nitro-BSA) in chronic fatigue syndrome (CFS) and major depression: evidence that nitrosative stress is another factor underpinning the comorbidity between major depression and CFS. Neuro Endocrinol Lett 2008, 29:313-319.

31. Herken H, Gurel A, Selek S, Armutcu F, Ozen ME, Bullut M, et al: Adenosine deaminase, nitric oxide, superoxide dismutase, and xanthine oxidase in patients with major depression: impact of antidepressant treatment. Arch Med Res 2007, 38:247-252.

32. Brunoni AR, Lopes M, Fregni F: A systematic review and meta-analysis of clinical studies on major depression and BDNF levels: implications for the role of neuroplasticity in depression. Int J Neuropsychopharmacol 2008, 11:1169-1180.

33. Ricken R, Adli M, Lange C, Krusche E, Koehler S, Hellweg R, Nase S, Richter C, Bschor T, Steinacher B, Rapp M, Borgwardt S, Lang UE: Reduced BDNF serum concentrations in acute depressive patients 
increased during lithium augmentation of antidepressants. J Clin Psychopharmacol 2013. in press.

34. Hock C, Heese K, Muller-Spahn F, Huber P, Riesen W, Nitsch RM, Otten U: Increased cerebrospinal fluid levels of neurotrophin 3 (NT-3) in elderly patients with major depression. Mol Psychiatry 2000, 5:510-513.

35. Rosa AR, Frey BN, Andreazza AC, Cereser KM, Cunha AB, Quevedo J, Santin A, Gottfried C, Goncalves CA, Vieta E, Kapczinski F: Increased serum glial cell line-derived neurotrophic factor immunocontent during manic and depressive episodes in individuals with bipolar disorder. Neurosci Lett 2006, 407:146-150.

36. Evans SJ, Choudary PV, Neal CR, Vawter MP, Tomita H, Lopez JF, Thompson RC, Meng F, Stead JD, Walsh DM, Myers RM, Bunney WE, Watson SJ, Jones EG, Akil $\mathrm{H}$ : Dysregulation of the fibroblast growth factor system in major depression. Proc Natl Acad Sci USA 2004, 101:15506-15511.

37. Lang UE, Hellweg R, Bajbouj M, Gaus V, Sander T, Gallinat J: Genderdependent association of a functional NGF polymorphism with anxiety-related personality traits. Pharmacopsychiatry 2008, 41:196-199.

38. Beaulieu JM: A role for Akt and glycogen synthase kinase- 3 as integrators of dopamine and serotonin neurotransmission in mental health. Psychopharmacol 2010, 30:135-144.

39. Ackermann TF, Kempe DS, Lang F, Lang UE: Hyperactivity and enhanced curiosity of mice expressing PKB/SGK-resistant glycogen synthase-3 (GSK-3). Cell Physiol Biochem 2010, 25:775-786.

40. Lang UE: Impairment of phosphatidylinositol 3-kinase signaling in schizophrenia: state or trait? Am J Psychiatry 2010, 167:719.

41. Naito Y, Takagi T, Okada H, Omatsu T, Mizushima K, Handa O, Kokura S, Ichikawa H, Fujiwake H, Yoshikawa T: Identification of inflammationrelated proteins in a murine colitis model by $2 \mathrm{D}$ fluorescence difference gel electrophoresis and mass spectrometry. J Gastroenterol Hepatol 2010, 25:S144-S148.

42. Bourdi M, Demady D, Martin JL, Jabbour SK, Martin BM, George JW, Pohl LR: cDNA cloning and baculovirus expression of the human liver endoplasmic reticulum P58: characterization as a protein disulfide isomerase isoform, but not as a protease or a carnitine acyltransferase. Arch Biochem Biophys 1995, 323:397-403.

43. Garbi N, Tanaka S, Momburg F, Hämmerling GJ: Impaired assembly of the major histocompatibility complex class I peptide-loading complex in mice deficient in the oxidoreductase ERp57. Nat Immunol 2006, 7:93-102.

44. McHugh PC, Rogers GR, Loudon B, Glubb DM, Joyce PR, Kennedy MA: Proteomic analysis of embryonic stem cell-derived neural cells exposed to the antidepressant paroxetine. J Neurosci Res 2008, 86:306-316.

45. Vaccarino V, Brennan ML, Miller AH, Bremner JD, Ritchie JC, Lindau F, Veledar E, Su S, Murrah NV, Jones L, Jawed F, Dai J, Goldberg J, Hazen SL: Association of major depressive disorder with serum myeloperoxidase and other markers of inflammation: a twin study. Biol Psychiatry 2008, 64:476-483.

46. Danese A, Moffitt TE, Pariante CM, Ambler A, Poulton R, Caspi A: Elevated inflammation levels in depressed adults with a history of childhood maltreatment. Arch Gen Psychiatry 2008, 65:409-415.

47. Markovitz JH, Shuster JL, Chitwood WS, May RS, Tolbert LC: Platelet activation in depression and effects of sertraline treatment: an open-label study. Am J Psychiatry 2000, 157:1006-1008.

48. Bilici M, Efe H, Köroğlu MA, Uydu HA, Bekaroğlu M, Değer O: Antioxidative enzyme activities and lipid peroxidation in major depression: alterations by antidepressant treatments. J Affect Disord 2001, 64:43-51.

49. Srivastava N, Barthwal MK, Dalal PK, Agarwal AK, Nag D, Seth PK, Srimal RC, Dikshit M: A study on nitric oxide, beta-adrenergic receptors and antioxidant status in the polymorphonuclear leukocytes from the patients of depression. J Affect Disord 2002, 72:45-52.

50. Kodydková J, Vávrová L, Zeman M, Jiák R, Macášek J, Staňková B, Tvrzická E, Žák A: Antioxidative enzymes and increased oxidative stress in depressive women. Clin Biochem 2009, 42:1368-1374.

51. Lang UE, Borgwardt S: Molecular mechanisms of depression: perspectives on new treatment strategies. Cell Physiol Biochem 2013, 31:761-777.

52. Bremner JD, McCaffery P: The neurobiology of retinoic acid in affective disorders. Prog Neuropsychopharmacol Biol Psychiatry 2008, 32:315-331.

53. Misner DL, Jacobs S, Shimizu Y, de Urquiza AM, Solomin L, Perlmann T, De Luca LM, Stevens CF, Evans RM: Vitamin A deprivation results in reversible loss of hippocampal long-term synaptic plasticity. Proc Natl Acad Sci USA 2001, 98:11714-11719.
54. Chen X, Meng Q, Bao A, Swaab DF, Wang G, Zhou J: The involvement of retinoic acid receptor in corticotropin-releasing hormone gene expression and affective disorders. Biol Psychiatry 2009, 66:832-839.

55. Katsuki H, Kurimoto E, Takemori S, Kurauchi Y, Hisatsune A, Isohama Y, Izumi Y, Kume T, Shudo K, Akaike A: Retinoic acid receptor stimulation protects midbrain dopaminergic neurons from inflammatory degeneration via BDNF-mediated signaling. J Neurochem 2009, 110:707-718.

56. Kino T, Jaffe H, Amin ND, Chakrabarti M, Zheng YL, Chrousos GP, Pant HC: Cyclin-dependent kinase 5 modulates the transcriptional activity of the mineralocorticoid receptor and regulates expression of brain-derived neurotrophic factor. Mol Endocrinol 2010, 24:941-952.

57. First MB, Spitzer RL, Gibbon M, Williams JBW: User's Guide for the Structured Clinical Interview for DSM-IV Axis I Disorders-Clinician Version (SCID-CV). Washington, DC: American Psychiatric Press; 1997.

doi:10.1186/1477-5956-12-1

Cite this article as: Huang et al:: 2D-DIGE proteome analysis on the platelet proteins of patients with major depression. Proteome Science 2014 12:1.

\section{Submit your next manuscript to BioMed Central and take full advantage of:}

- Convenient online submission

- Thorough peer review

- No space constraints or color figure charges

- Immediate publication on acceptance

- Inclusion in PubMed, CAS, Scopus and Google Scholar

- Research which is freely available for redistribution 